\title{
Granting Market Economy Status to China in the EU: An Economic Impact Assessment
}

Cecilia Bellora \& Sébastien Jean

\section{Summary}

This Policy Brief assesses the possible economic impacts for the European Union of granting market economy status (MES) to China in antidumping investigations. The issue is important: China ranks first among the countries targeted by European antidumping, and sanctions cover tariff lines worth $8.7 \%$ of EU imports from China, based on pre-investigation imports $(0.5 \%$ for MES partners).

We find that China's exports face a larger number of antidumping investigations than those from MES partners, even accounting for China's trade specificities. These investigations also have a higher chance of being won by the plaintiff. Furthermore, when a sanction is decided, its trade-restrictive impact is higher against China. In addition, we show that antidumping measures lead not only to an increase in the prices of targeted Chinese products but also in those of Chinese untargeted products similar to those directly targeted. This chilling effect materializes in 4 to $14 \%$ prices increases for untargeted exports belonging to the same sector as those targeted. It does not affect MES partners.

Antidumping cases against non-MES partners other than China are not numerous enough to isolate the impact of the MES per se. We thus assess the impact of granting MES to China assuming that all China's specificities in EU antidumping procedures would disappear as a result. Under this assumption, disregarding the chilling effect, changing China's status would boost its exports to the EU by $3.9 \%$ to $5.3 \%$ in volume (€13bn to $€ 18 \mathrm{bn})$. Factoring in the removal of the present chilling effect, the impact might reach $7.4 \%$ to $21 \%$ in volume (€25bn to $€ 72 \mathrm{bn}$ ). Domestic output losses would be small in relative terms (up to $0.06 \%$ disregarding the chilling effect, up to $0.32 \%$ taking it into account), but significant in absolute terms (respectively, $€ 3.9 \mathrm{bn}$ and $€ 23 \mathrm{bn}$ ); $90 \%$ of these impacts reflect the decline in the number of investigations, as opposed to the level of duty in case of sanction. Accordingly, dropping the so-called lesser duty rule would not alter significantly these impacts. 
On 11 December 2016, precisely 15 years after China officially joined the World Trade Organization (WTO), the provisions of subparagraph (a)(ii) of article 15 of its accession protocol will expire. According to this subparagraph, for producers that cannot show that their industry follows market rules, a methodology "not based on a strict comparison" with Chinese costs is allowed when dealing with antidumping investigations. Such a methodology, relying on an analogue country to establish dumping, is only allowed under WTO law when dealing with non-market economies, a rather restrictive definition according to agreements and jurisdiction. It is commonly considered to result in tougher protection than the standard methodology.

This prospect is fueling heated debates because the expiration of these provisions is subject to different interpretations. Chinese authorities have made it clear that they consider it to mean that market economy status (MES) should automatically be granted to China, and that they attach strong value to the matter, not only from an economic but also from a symbolic point of view. Its partners now need to decide whether to change their policy because of this expiration; granting a trading partner MES is a decision for each country, even though not granting it can be challenged through the WTO Dispute Settlement Body. While the United States administration has signaled its willingness not to change its present policy with regards to China, the issue remains under discussion in the EU.

The stakes are high, because China is the world's largest exporter and ranks first among the EU's good import partners, and because antidumping is the most widely used trade defense instrument, and the one that influences trade patterns the most. However, the debate on the matter is obscured by the technicality of antidumping (AD) procedures and by the difficulty of figuring out what different options may arise in practice. China is by far the main target of the EU'S AD investigations, but would things change under MES, and to what extent? The reply is far from obvious, because China's size, competitiveness and trading practices are also part of the explanation for the present situation. Similarly, while $A D$ sanctions are on average more trade-restrictive against Chinese exporters, to what extent this difference is linked to MES is an open question.

The objective of this Policy Brief is to shed light on the possible economic impacts of granting China MES, focusing on the EU. It does not attempt to contribute to the legal or political related questions, but merely to propose an assessment of the mechanisms involved and of their consequences, based on an analysis of all $A D$ investigations and sanctions in the EU since 1988. Ideally, we would like to characterize how non-marketeconomy (NME) partners differ from MES partners in that respect. However, given the small number of NME partners and the limited trade importance of most of them outside China, drawing robust statistical inference for NME partners other than China did not prove possible. Our analysis thus focuses on assessing how China differs from MES partners in terms of determinants and consequences of $A D$ investigations in the EU. The consequences of granting China MES are then assessed, assuming away these differences. Two possible biases associated with this method are worth mentioning, one positive, the other negative.

The first possible bias relates to the fact that centrally planned economies are more likely to engage in dumping practices, since their firms' pricing strategies are more likely to depart from market mechanisms. This is notably the case for China; its government-planned industrial strategy is widely documented, and involves a number of different instruments, including direct and indirect subsidies and concessional finance. Among recent illustrations of the consequences of such policies is the large and rapid increase in investment in the steel industry, accelerated in the aftermath of the economic and financial crisis in 2009-2010, i.e. at a time when the government was willing to use investment to boost the economy even though demand was slacking. As a result, China now holds more than half the world's production capacities in this sensitive sector, where pricing strategies cannot be assessed independently from investment and financing conditions. Accordingly, the difference measured between $A D$ cases against China and those against MES partners may not entirely be due to the European procedure, but also partly to China's practices, over and above what can be controlled by observable variables such as employment or import prices and quantities. In this sense, our analysis may be biased toward overestimating the impact of MES on the EU's AD cases against China.

The second possible bias would ensue from focusing exclusively on direct effects. Indeed, the risk of facing an $A D$ case may act as a deterrent for exporters of goods not directly targeted, leading them to limit their sales or to apply higher prices. While the evidence for such a "chilling effect" remains scant and mixed (Vandenbussche \& Zanardi, 2010; Egger \& Nelson, 2011), its relevance cannot be ruled out. If NME status indeed implies a higher risk of facing an $A D$ case, or tougher expected sanctions when a case is raised, then being granted MES may lift a brake on exports even for products not directly targeted. As a result, focusing on direct effects may lead to underestimating the impact of granting MES. In what follows, we propose an assessment of this chilling effect, and assess the possible corresponding indirect effects on trade and production

We begin by recalling what is at stake through this debate on MES, and by giving descriptive statistics about the EU's AD practices. We then assess the determinants and consequences of $A D$ investigations, through an econometric analysis that focuses on the difference between China and MES partners. The results are used to simulate how granting China MES might influence the EU's imports, and what the consequences might be for EU producers and consumers, under reasonable assumptions. We conclude by discussing the implications for the EU's trade policy. 


\section{Market economy status and antidumping procedures: what are we talking about?}

\subsection{Dumping, anti-dumping and non- market economies}

According to the World Trade Organization (WTO) definition, a product is dumped if it is exported at a price lower than what the exporter charges in its domestic market. Importing industries can ask their governments for protection against dumped imports, in compliance with the Antidumping Agreement. Possible protection consists of duties (ad valorem or specific) or, more rarely, price or quantity undertakings, specifically targeting the product and the exporter for which dumping is proved, set so as to bring the import price to the level of the "normal value", i.e. the price that would prevail in the absence of dumping. Protection is temporary and must be removed once dumping has stopped. The calculation of the "normal value" is key. In general, it is the price of the product at issue, "in the ordinary course of trade", when sold for consumption in the domestic market of the exporting firm. But in the so-called "non-market economies", where domestic prices are considered unreliable since they can be distorted by governmental interventions, alternative methodologies are allowed. The WTO legal texts are not binding in this case, and let importing countries apply discretion (see Box 1 for details). For instance, the European Union uses the domestic prices of a third country to determine the "normal value" of a good exported by a non-market economy (NME), while the US applies production factors prices of a third country to the production technology of the NME country considered (see Box 2 for details on US antidumping (AD) procedures).

China's protocol of accession to the WTO opens up the possibility of recourse to the calculation methodologies in use for NMEs when it comes to Chinese exports, unless Chinese producers under investigation clearly show that market-economy conditions prevail in their industry. It also includes provisions related to the expiration of the use of such methodologies. However, the interpretation of these provisions is subject to two polar interpretations. One holds that China should be granted MES without restriction or condition. The other holds that the repeal is only partial and that, as far as antidumping procedures are concerned, there is no obligation to treat China as a market economy.

Whether to grant MES to China is an issue not only for the EU but also for the other WTO members. New Zealand, Australia, Peru, Chile and ASEAN countries have already granted standard antidumping treatment to China in the framework of the negotiation of free-trade agreements (Puccio, 2015). South Africa did the same in a record of understanding. The United States and India, two of the main users of antidumping instruments, have not yet made official their position.
Box 1 - Antidumping procedure and European specificities

Antidumping measures being an exception to the principles of binding tariffs and of non-discrimination between trading partners, conditions under which WTO members can use them are set in the Antidumping Agreement, which expands Article VI of the GATT. This agreement specifies how to determine dumping, the resulting injury, and the causal link between injury and dumping, and sets the applicable investigation procedures. It also includes the "sunset" requirement stipulating that antidumping measures shall terminate no later than five years after they went into force, unless the importing country shows that their removal would lead to the continuation of dumping. The reference to non-market economies and alternative methodologies is made in Annex I to the GATT (Addendum to Article VI of the GATT). Nevertheless, neither Article VI nor the Antidumping Agreement specifies the contents of these methodologies.

European antidumping procedures are set by Regulation 1225/2009 of the European Union. It includes a list of countries considered as nonmarket economies (Albania, Armenia, Azerbaijan, Belarus, Georgia, North Korea, Kyrgyzstan, Moldova, Mongolia, Tajikistan, Turkmenistan and Uzbekistan), as well as a list of countries treated with the same rules as NMEs except for producers that are able to demonstrate that market conditions prevail in their industry (People's Republic of China, Vietnam, Kazakhstan and any NME that is a member of the WTO). It also establishes some specificities with respect to the WTO's rules:

- The European Commission systematically verifies that "the Community interest calls for intervention" prior to taking an antidumping measure. For this purpose, the status of "interested parties" is extended to users and consumer organizations. This criterion has generally played a minor role in the past, but its analysis has become more detailed over time (Van Bael \& Bellis, 2011). In 2015, when opening an interim review of duties on solar panels (EC, 2015b), the Commission invoked the fact that excessively high antidumping duties could result in reduced competition among European producers and would therefore be against Community interests.

- The European Union applies the so-called "lesser duty rule": duties are set to a level lower than the dumping margin if this level is sufficient to remove the injury to the European industry, while other countries set duties at the level of the dumping margin, the highest level allowed by the WTO.

- Concerning NMEs, the EU calculates normal values based on the normal values of a third country, to be "selected in a not unreasonable manner", in each investigation. Actually, this choice is mainly empirical and often dictated by the willingness of the producers of the third country to disclose to the Commission details of their production costs and margins (Van Bael \& Bellis, 2011). As a result, a wide variety of countries are used as the analogue country, depending on the products considered (recent examples are Canada or South Africa in the steel industry, Turkey and India for solar panels and glasses, or even, since no cooperative third country was found, the EU industry in the chemical sector).

- The European regulation does not specify criteria to define a nonmarket economy. Only criteria to determine whether market conditions prevail in a specific industry are listed (Article 2.7(c)). However, by extension, the same five criteria are used by the European Commission to evaluate whether to grant MES to countries that ask for it (EC, 2015a). China unsuccessfully requested this status in 2004, the Commission considering that only one of the five criteria was met. 


\section{Box 2 - Comparison between US and European antidumping}

The US is a tough user of antidumping, in terms of both number of cases and level of duties. Trade affected is larger in the US than in the EU: in 2011, 3.9\% and $1.7 \%$ of US and EU imports, respectively, were covered by an $A D$ duty (Blonigen, 2015). Bilateral coverage with China follows the same trend, being equal to $9.1 \%$ in the US and $7.3 \%$ in the EU. Given the similar win rates observed on both sides of the Atlantic, the difference likely comes from higher initiation rates that can be linked to easier petition filling procedures in the US. Antidumping duties are also higher in the US. Considering cases initiated from 2002, the average US $A D$ rate against China is $162 \%$, with a maximum at $430 \%$, while the average European rate is $43 \%$, with a peak at $91 \%$. Higher duties also apply to MES (33\% on average in the US, $21 \%$ in the EU). The European "lesser duty rule" explains part of this difference: Dumping margins found by the European Commission average $63 \%$ against China, and $43 \%$ when all trading partners are considered, which is closer to US duties (set equal to dumping margins in the US) but still significantly lower. High US duties also result from adverse inferences used to determine the normal value. Where not all information is available, the WTO Agreement on Antidumping allows us to use available facts to complete dumping and injury determinations. In case of the non-cooperation of an interested party, the US goes further, using "adverse inferences", i.e. choosing among available facts those adverse to the interest of the non-cooperating party, including information contained in the petition filed by the complainant. Extremely high duty rates applied by the US systematically result from adverse inferences. Recently, the Trade Preferences Extension Act of $2015^{*}$ made it even easier for the US Department of Commerce to resort to adverse inferences, and makes dumping decisions based on these inferences more difficult to challenge in the courts. The "zeroing" practice also contributed to higher dumping margins found by the US in the 2000s. In short, under this practice, non-dumped sales cannot offset dumped ones, resulting almost always in a positive average dumping margin. Zeroing has long been used by both the
European Union and the US, but was stopped by the EU in 2001 while in use in the US until 2007. Furthermore, zeroing is still used by the US in administrative reviews (these annual reviews, at the request of any interested party, can modify dumping margins and resulting duties).

As far as specific NME methodologies are concerned, adverse inferences are particularly easy to justify in US procedures. Indeed, in the US, NME companies are not eligible to individual treatment unless they ask for and pass eligibility tests. Individual treatment is rare; all other companies are given an economywide rate, the Department of Commerce considering that all exporters are subject to government control and therefore deserve a common duty rate. When determining an economy-wide rate, arguments to use adverse inferences are easier to find, resulting in the extremely high $A D$ rates imposed by the US. The European Union does not make a clear reference to "adverse inferences", even if it can freely choose among available facts. Furthermore, it grants individual treatment to all exporters, which limits the cases of non-cooperation that justify the use of adverse inferences. ${ }^{* *}$ Methodologies applied to NMEs also differ between the US and $\mathrm{EU}$ in the way information from third countries is used to compute normal values. The US Department of Commerce identifies the production factors used by NME producers and applies to them prices taken from a surrogate country. This surrogate country is a market economy at a level of development comparable to the NME considered, and a significant producer of the product investigated. Often, India is the surrogate country chosen in cases against China (GAO, 2006). This differs from European methodologies in two ways: First, the EU considers the production technology (i.e. quantities of production factors) of the surrogate country and not of the NME in question to compute the normal value. Second, the choice of the surrogate country is less constrained in Europe, since a similar development level is not mandatory. Nevertheless, it is not clear how these differences in the choice and use of third countries may affect the applied AD duties.

* https://www.congress.gov/bill/114th-congress/house-bill/1295/text

** The European Union used to apply countrywide rates to NMES, but ceased to do so in 2012, after having lost a WTO dispute against China. Since then, all exporters, irrespective of the methodology used to calculate their normal value, are granted individual treatment.

\subsection{Descriptive statistics: China is the main target of European antidumping}

To summarize existing and past practices, we rely on the Global Antidumping Database (GAD) put together by the World Bank (Bown, 2015), completed as needed by detailed information published by the European Commission on each investigation. All antidumping investigations initiated between 1988 and the end of 2015 are taken into account. ${ }^{1}$ Antidumping reviews can terminate or modify duties, change the list of individual exporters sanctioned, or extend the number of countries affected, in particular to deal with circumvention of the initial measures. We do not consider here any review; only information on the termination of a duty is retained. Even though investigations and sanctions are targeted at individual firms, the published

(1) For more details on data sources and treatments, see the Appendix, available online: http://www.cepii.fr/PDF_PUB/pb/2016/pb2016-11_app.pdf information does not make it possible to carry out the analysis at this level. Accordingly, we make use of the most detailed trade statistics available, those published by Eurostat at the tariff line level (8-digit Combined Nomenclature, defined yearly for about 10,000 products). Following Bown (2015), the antidumping duty we consider on each tariff line is the higher imposed among firms concerned in the investigation.

The European Union is a traditional user of antidumping measures, like the United States and Canada (Blonigen \& Prusa, 2015). By the end of 2015, 87 antidumping measures were in force in the EU, affecting 378 tariff lines and targeting 16 trading partners. More than half these measures affected China, which was involved in 51 active measures covering 215 products. This focus on China is even more striking when considering the gap with the following most targeted countries: Russia, involved in seven measures affecting 26 products, and the USA, involved in four measures, with 28 products. As a result, in $2015,2.7 \%$ of 
Figure 1 - Share of trade in the tariff lines affected by antidumping measures - Based on current trade

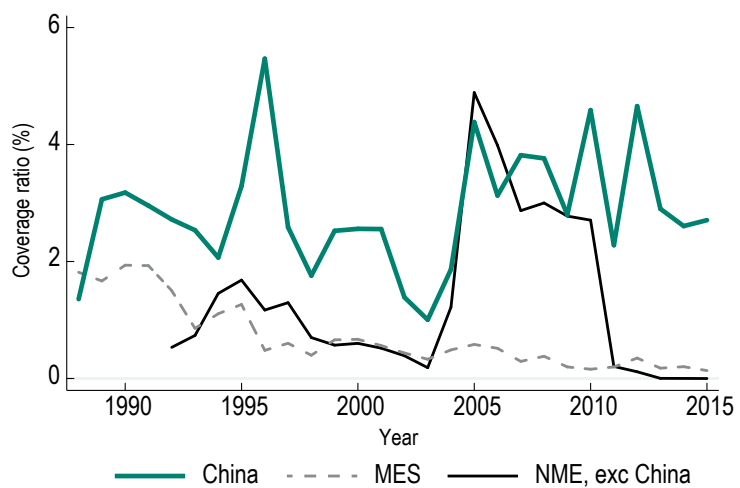

Source: Author's calculations, based on Bown (2015), Eurostat Comext and information published by the European Commission on each investigation.

bilateral imports (in value) with China were made in tariff lines targeted by antidumping measures, ${ }^{2}$ to be compared with $0.1 \%$ for countries having MES, and almost $0 \%$ for countries without MES, excluding China, as shown in Figure 1.3 The coverage rate is especially unstable for NME partners; the relatively limited importance of these partners in EU external trade makes the analysis of the pattern of $A D$ investigations against their exporters dependent on a small number of cases, so that specific cases may strongly affect the aggregate indicators. For instance, the $A D$ case against imports from Vietnam of footwear with leather uppers initiated in 2005 and terminated in 2011 explains the much larger coverage rate observed between 2005 and 2010, in particular because it involves tariff lines in which large volumes are traded. This illustrates the fact that NME partners are too small a group to enable robust statistical inference about the EU's AD patterns with respect to them. Although significant variability is also observed for China (the most recent spike being due to the emblematic antidumping case against Chinese solar panels initiated in 2012 and still in force), the contrast with MES partners - more pronounced during the last decade than the one before - is striking.

However, shares of imports affected by $A D$ are understated almost by definition, as a result of the trade-cutting impact of $A D$ measures. To overcome this endogeneity bias, we follow Bown (2011) and compute alternative coverage rates whereby each case weight is measured through its share in bilateral imports in the year preceding the investigation initiation, instead of the current year. ${ }^{4}$ Even though figures for NME partners still exhibit pronounced instability, making their interpretation difficult, a clearer picture emerges from the use of this alternative method

(2) Often, only a fraction of the eight-digit tariff line is involved in the AD but information on trade is not available at such a detailed level. In these cases, we consider trade flows of the whole tariff line. Hence, our figures on AD trade coverage should be considered as an upper bound.

(3) By the end of 2015, there was only one active case against an NME other than China, relating to iron tubes imported from Belarus.

(4) Using annual trade data, we consider that bilateral trade flows are affected by antidumping measures as from the initiation year.
Figure 2 - Share of trade in the tariff lines affected by antidumping measures - Based on trade on the year before initiation

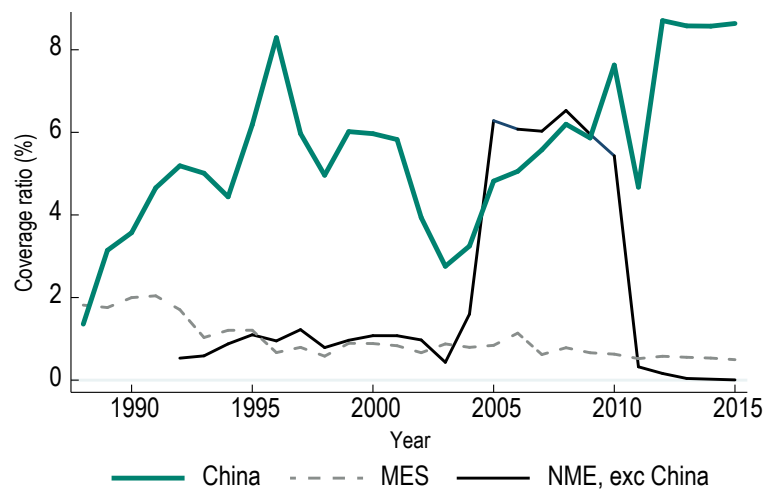

Source: Author's calculations, based on Bown (2015), Eurostat Comext and information published by the European Commission on each investigation.

(Figure 2). For MES partners, the coverage of $A D$ measures has been rather low and declining slowly but continuously since the early 1990 s, reaching $0.5 \%$ in 2015 . For China, in contrast, coverage has been comparatively large since the early 1990s, and it has been significantly and almost continuously increasing since 2003 , reaching $8.7 \%$ in 2015 . Not only are the cases against China more frequent, but they also involve higher duties, averaging $43 \%$, than those applied to market economies (19\% on average in 2015). Duties applied to China have been historically higher, but the difference with respect to duties applied to market economies has increased in the last ten years (see the Figure in the Appendix ${ }^{5}$ ): for instance, in 2005, average duties applied to China and to market economies differed by only seven percentage points.

As widely documented in the economic literature, $A D$ investigations are highly concentrated on a limited number of sectors, with the steel industry playing a central role in most cases (e.g. Blonigen \& Prusa, 2015; Durling \& Prusa, 2006). The pattern of protection is mainly linked to the characteristics of domestic industries (Blonigen \& Prusa, 2015; Bown \& Crowley, 2016); high fixed costs and concentrated industries have a greater ability to organize politically and to file $A D$ petitions. As a matter of fact, NMEs and MES differ in the magnitude of trade coverage, but not much in terms of sectors mostly affected (Figure 3 and Figure 4). In 2015, AD duties were most applied in the steel and chemical sectors; coverage rates differed in magnitude between China (30\% and $13 \%$ respectively) and countries with MES (3.4\% and 3.2\%), but in both cases were higher than in other sectors. While the electronic sector is affected throughout the period, AD cases were mainly aimed at electronic sound and video equipment in the early 1990s, while the present peak in import coverage concerns solar panel components.

Countries shifting status are of special interest for our purpose. Two interesting cases arose in the European Union: Russia

(5) The Appendix is available online: http://www.cepii.fr/PDF_PUB/pb/2016/ pb2016-11_app.pdf 
Figure 3 - Share of trade in tariff lines affected by antidumping measures, by sector - MES

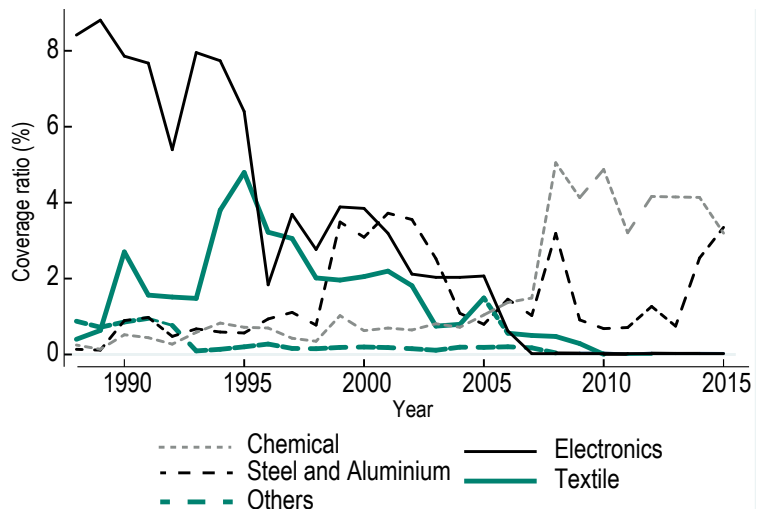

Source: Author's calculations, based on Bown (2015), Eurostat Comext and information published by the European Commission on each investigation.

and Ukraine, which were granted MES in December 2002 and December 2005, respectively. ${ }^{6}$ While the limited number of cases before and after status change makes it impossible to infer statistical evidence, in both cases AD coverage has been trending downward since MES was granted (see the Figure in the Appendix). In Russia, the overwhelming importance of energy products probably contributes to blur the picture, making it difficult to interpret. For Ukraine, the downward trend is very clear, especially when the coverage is computed based on import shares computed during the year before initiation. Based on this metric, the coverage rate, hovering between $4 \%$ and $5 \%$ during the seven years preceding the shift to MES, plummeted subsequently to levels lower than $1 \%$ during the last three years.

While these statistics suggest significant difference in treatment between China and MES partners, they are only descriptive, and may also reflect the distinctive position of China in EU trade relationships, marked by low prices and high and quickly increasing market shares. To better understand these differences, we now turn to a more elaborate analysis.

\section{An empirical analysis of the impact of MES on antidumping use and on imports}

By altering the way normal import values are computed, the analogue-country methodology applied to NME countries gives additional leeway in carrying out $A D$ investigations. It can have four possible consequences on imports from NME partners. First, NME exporters may face more AD investigations since would-be plaintiffs are more likely to win the case they consider raising. Second, because methodologies applied to NME partners result in higher dumping and injury margins, $A D$ investigations may result

(6) Lithuania, Latvia and Estonia were also granted MES in 1995, but their examples are of limited relevance as a benchmark for other countries, since the use of $A D$ against them has been influenced by their accession process to the EU.
Figure 4 -Share of trade in tariff lines affected by antidumping measures, by sector - China

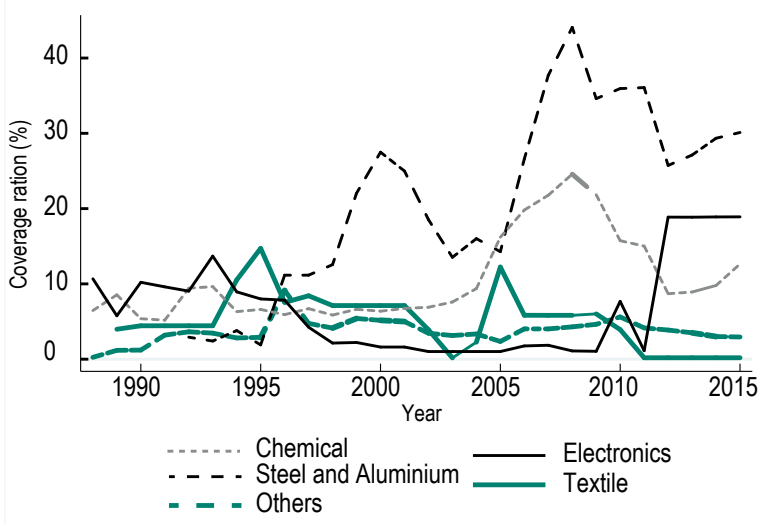

Source: Author's calculations, based on Bown (2015), Eurostat Comext and information published by the European Commission on each investigation.

more often in sanctions. Third, sanctions may be tougher, with higher import-cutting impacts. And fourth, they may be maintained for a longer period. While too few observations are available to assess robustly the fourth element, we successively analyze econometrically the first three elements in order to figure out to what extent China differs from MES partners.

\subsection{China is more likely to face AD investigations}

$A D$ cases only concern a limited number of sectors. For manufacturing products in those sectors, between 1995 and 2014, the probability of a given MES partner facing an $A D$ investigation on a given product not already subject to an ongoing sanction was on average $0.05 \%$, according to our calculations. For China, this probability was $0.53 \%$. This difference is substantial, yet its interpretation is not straightforward. Since Chinese exporters are more numerous and enjoy larger market share than those of most other partners (and in many cases, of all of them), it is more likely that one of them will be charged with dumping. In addition, Chinese exporters are known to be practicing low prices and to sell laborintensive products, which also contributes to making them natural targets for $A D$ investigations. Figuring out what role MES, or the lack thereof, may play in this difference thus requires other known, observable determinants to be controlled for. This is the aim of the econometric estimates presented below.

According to the literature, these determinants relate to dumping margins, but also to bargaining power and coordination costs (see Zanardi, 2004; Blonigen \& Park, 2006; Blonigen \& Park, 2015, for a survey). The first obvious determinants include the level and change in import prices, since they are directly linked to dumping allegations, as well as to incentives for domestic industry groups to lodge a complaint. Another relevant determinant is the penetration ratio of imports, which determines the intensity of the threat that imports may represent to domestic producers. Both its level and change over time can be an incentive for domestic industries to 
file an $A D$ petition, and are examined by government agencies to evaluate dumping and injury margins. The number of jobs in the plaintiff sector may be relevant as well because it is an indicator of its bargaining power and the possible pressure it can apply in the political arena (Zanardi 2004). It is also an indicator of the size of the industry and its role in the national economy. Furthermore, larger industries anticipate a higher positive outcome of their complaints and could tend to lodge more complaints. Beyond level, changes in employment rates should also be considered. Indeed, declining sectors face lower coordination costs to file $A D$ petitions, and overcome more easily coordination failures, to the extent that the potential benefits of a successful complaint will not have to be shared with newcomers. In addition, the number of previous initiations of $A D$ cases in the sector is relevant because it is an indicator of coordination costs as well as experience. Finally, since the propensity to rely on trade defense instruments is likely to be influenced by macroeconomic shocks (Bown \& Crowley, 2013), controlling for year-specific effects may be a worthwhile addition. Over the considered period, the number of cases against NMEs other than China is not sufficient to identify robustly the determinants of their initiation: only 35 investigations for which all independent variables are not missing are available. We therefore limit the analysis to China and MES partners.

Estimating the probability of a given partner facing an $A D$ investigation on a given product as a function of these determinants gives statistically significant coefficients, with the expected sign, for each of them, except the lagged change in employment share (Table 1, column 1). An AD investigation is more likely if the sector employs more people in the EU; if the partner import penetration ratio is large and increasing; if the average unit value ${ }^{7}$ of its sales to the EU is low and falling, and if a larger number of investigations were initiated in the last seven years in the sector the product belongs to.

Having thus controlled for the influence of other determinants makes it possible to focus meaningfully on China's specificity, assessed here through a dummy variable denoting that the partner is China. The result is positive and significant: even taking their measurable specificities into account, the probability of facing an $A D$ investigation is higher for China's exports, by 0.32 percentage points. Given the sample mean of the dependent variable $(0.05 \%)$, this is a huge difference, which is likely attributable in large part to the NME status.

The results are robust to including sector fixed effects (column 2); altering the measure of the number of past investigations (column 3); including product fixed effects (column 4), and considering only cases initiated after China's accession to the

(7) Average unit values are computed in relative terms with respect to other exporters, using import value share the year before as a weighting scheme. Change over time is computed as a Laspeyres index.
Table 1 - Determinants of the probability to initiate an antidumping investigation robability in \%)

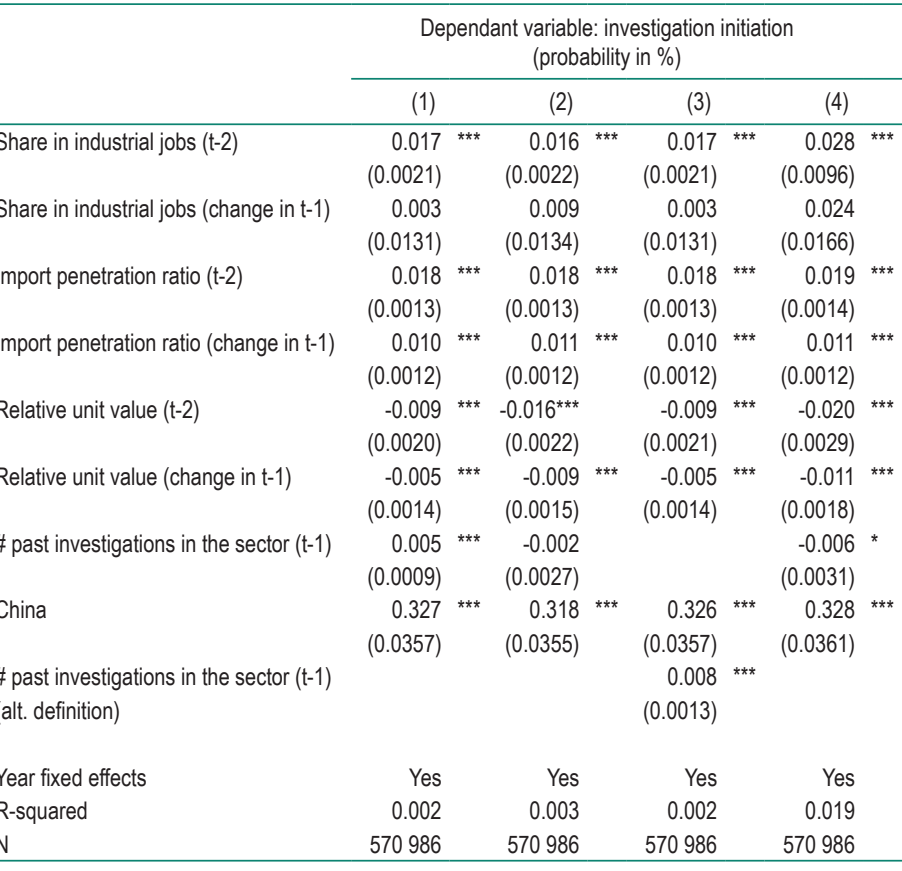

Cope: Manufacturing products, 1995 - 2014. Partners other than China that are not granted MES are excluded from the sample, due to the insufficient number of observations for such cases. Only chapters here at least one antidumping case was raised between 1995 and 2015 are considered

te: estimation (2) includes sector fixed effects, (3) considers the number of past (

$0.10,{ }^{* *} p<0.05,{ }^{* * *} p<0.01$

rce: Authors' calculations. For more details on data sources and treatments, see the Appendix.

WTO. The only meaningful change concerns the influence of past investigations, which is not significant when product or sector fixed effects are included, presumably because this variable exhibit limited time variability, and is therefore strongly positively correlated with such fixed effects. China's estimated specificity, in particular, is highly robust across specifications.

To sum up, we find that China's exports face a far larger number of $A D$ investigations than MES partners, even when accounting for its measurable trade specificities.

\subsection{Investigations against China are more likely to be won}

The second question is whether, once initiated, $A D$ investigations are more likely to result in an affirmative determination of dumping (and therefore in sanctions) if the partner is China. ${ }^{8}$ Here again, prima facie evidence suggests that this is the case, since the win rate (i.e. the probability of affirmative decision) is $59 \%$ for MES partners, but $76 \%$ for China. As before, though, factors other than MES may influence the win rate for China; for instance, the

8) Withdrawal and termination are both considered as "negative" outcomes. Withdrawn complaints are interesting in themselves since they indicate the role played by $A D$ procedures in collusion among domestic and foreign industries (Prusa, 1992; Veugelers \& Vandenbussche, 1998; Zanardi, 2004), but grouping them makes sense in the present context, where we focus on cases resulting in $A D$ measures. 
larger size of its exporters' market share. To disentangle these influences, we carry out econometric estimates of this win rate, taking into account the same determinants included above in the analysis of initiation.

The estimates (presented in the Appendix) show, as expected, that a higher number of past investigations in the sector increases the win rate, presumably because of the accumulation of skills specifically needed in defending the industry's interest in the procedure. Lower unit values are also associated with a higher win rate, consistent with the idea that it is easier to prove dumping in such cases. The negative influence of the employment share is more surprising. A possible explanation may be that the larger influence of industries with more employees makes it possible for them to initiate more investigations, including in cases where dumping is more difficult to establish. Other factors are not significant.

Our main interest here is in China's specificity. Again, it turns out to be statistically significant and economically large: all else being equal, the win rate is 19 percentage points higher when the targeted partner is China than when it is an MES partner. The estimated difference is lower when sector fixed effects are taken into account, but still significant (11 p.p. in this case). Given the sample mean of the win rate (59\% for MES partners), this difference is actually very large, making China a strong outlier. Its NME status is a likely explanation for this finding, since the leeway it offers in the computation of normal values probably makes dumping easier to establish. The higher probability of winning a petition against Chinese exporters is robust to the same changes in specification as before. It is in line with the findings of Zanardi (2004) and Blonigen and Park (2004) on the impact of NME status on the positive outcome of US antidumping cases.

Summing up: Accounting for all observable determinants, we find that $A D$ investigations have a higher chance of being won by the plaintiff when aimed at Chinese exporters than at exporters from MES partners.

\subsection{AD cases have a stronger trade- restrictive impact for China, reflecting higher duties}

The third question we want to investigate is whether $A D$ sanctions, when imposed, have a different impact depending on MES. To ascertain whether this is the case, we adopt an event study approach, considering each $A D$ sanction applied to a given partner and a given tariff line as an event, of which the impact on trade can then be analyzed. We disregard $A D$ investigations where the plaintiff loses, because the trade impact is short-lived and far more limited in such cases. Here again, it proved impossible to evaluate in a robust way whether NMEs other than China present a significantly different pattern, due to the limited number of cases raised against the former (only 59 in the most basic specification below); our analysis thus simply contrasts China with MES trading partners. As before, we restrict the analysis to manufacturing products.

As documented in the literature (e.g. Prusa, 1992), an AD case may affect trade as of initiation of the investigation. To be able to take into account the pre-investigation trend, we begin the analysis three years before initiation. We extend it to four ${ }^{9}$ years after investigation.

The most straightforward way to analyze the trade impact of $A D$ cases is to measure changes over time in import volumes, relative to their level during the year when the investigation was initiated. Doing this shows that $A D$ cases massively reduced import volumes for all partners. While the impact is stronger for China (-70\% four years after investigation) than for market economies $(-60 \%)$, the difference is not statistically significant (Figure 5). However, this prima facie evidence does not control for a series of potentially influential factors. An obvious one is the pre-investigation trend: it is strongly increasing in both cases but, again, more strongly for China, with a doubling (a 0.65 log point increase) of import volumes on average over the two years before the year preceding an investigation. Beyond this, year- or sector-specific shocks may also bias the analysis.

To take these potential influences into account, we successively alter our econometric specification in several ways: including year fixed effects; expressing the dependent variable as the deviation from the pre-investigation trend, and computing this detrended ${ }^{10}$ dependent variable as the ratio of the partner's imports to imports from other untargeted ${ }^{11}$ extra-EU27 partners for the same product. The latter specification allows any time-specific determinant of

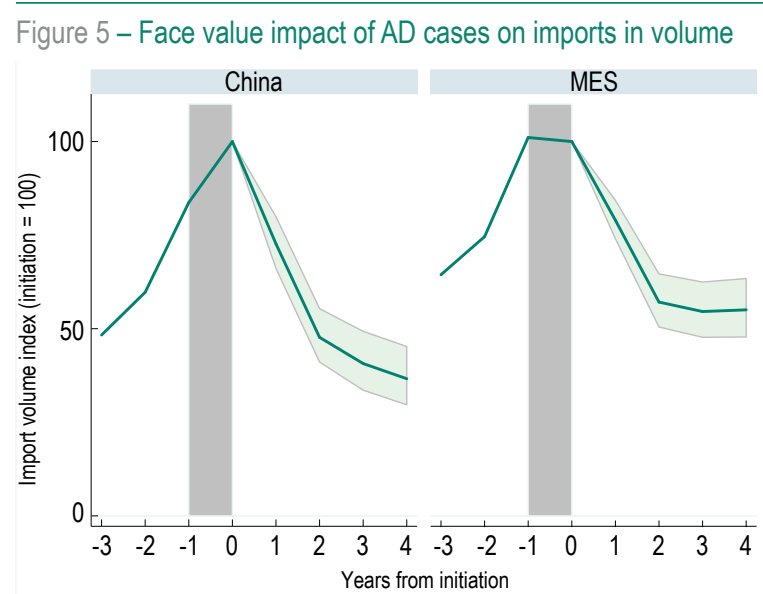

Sample: Antidumping cases regarding manufacturing products successfully raised in the European Union, 1988-2015. When the case covers several tariff lines, each one is considered separately (except when the definition is not spelt out at the 8-digit level). Using this definition, the sample includes 295 cases against China and 470 against MES countries. Avoiding counting several tariff lines for a given case, the sample includes 99 against China and 230 against MES partners.

Note: The solid line represents the unweighted average across AD cases. The shaded green area represents the $[5 \% ; 95 \%]$ confidence interval, based on an OLS estimation whereby the change of import volume (in log) is regressed against time to initiation. The estimating equation is $\ln \left(M_{t}^{g} / M_{0}^{g}\right)=\mathrm{a}_{\mathrm{t}}+\mathrm{u}_{\mathrm{t}}^{\mathrm{g}}$ where $M$ stands for import volume, $a$ is a parameter and $u$ is an error term. $t$ refers to time (measured as years from initiation) and $g$ to the tariff line targeted. Standard errors are clustered by individual case. While estimated in logarithms, the results are converted to indices for the sake of readability. Using annual data, slopes in the grey shaded areas are irrelevant.

Source: Authors' calculations. For more details on data sources and treatments, see the Appendix.

(9) We do not want to capture the impacts of "sunset reviews" which occur five years after the duty has been put in place (if it has not already been lifted)

(10) Details on data treatments are available in the Appendix.

(11) Only partners that are not targeted by an $A D$ case for the same product in a time window spanning from three years before investigation to four years after are considered. 
Table 2 - Estimated impact of AD cases on import volume for MES partners and additional impact for China

\begin{tabular}{|c|c|c|c|c|c|c|c|}
\hline & \multicolumn{2}{|c|}{$\begin{array}{l}\text { Import } \\
\text { volume }\end{array}$} & $\begin{array}{l}\text { Detrended } \\
\text { import } \\
\text { volume }\end{array}$ & $\begin{array}{l}\text { Detrended } \\
\text { import vol., } \\
\text { ratio to extra- } \\
\text { EU imports }\end{array}$ & $\begin{array}{l}\text { Import vol., } \\
\text { ratio to extra- } \\
\text { EU imports }\end{array}$ & \multicolumn{2}{|c|}{$\begin{array}{l}\text { Detrended } \\
\text { import vol., } \\
\text { ratio to extra- } \\
\text { EU imports }\end{array}$} \\
\hline & (1) & & (2) & (3) & (4) & (5) & \\
\hline \multicolumn{8}{|c|}{ Years from initiation (impact in \%) } \\
\hline Year 1 & $\begin{array}{r}-30.2 \\
(-3.24)\end{array}$ & $* * *$ & $\begin{array}{r}6.0 \\
(0.57)\end{array}$ & $\begin{array}{l}-25.5^{* * *} \\
(-5.16)\end{array}$ & $\begin{array}{l}-17.2^{* * *} \\
(-2.95)\end{array}$ & $\begin{array}{r}-21.1 \\
(-2.49)\end{array}$ & ** \\
\hline Year 2 & $\begin{array}{r}-50.7 \\
(-5.56)\end{array}$ & $* * *$ & $\begin{array}{l}-27.1^{* *} \\
(-2.45)\end{array}$ & $\begin{array}{l}-46.5^{* * *} \\
(-5.23)\end{array}$ & $\begin{array}{l}-23.1 \\
(-2.37)\end{array}$ & $\begin{array}{r}-8.8 \\
(-0.59)\end{array}$ & \\
\hline Year 3 & $\begin{array}{r}-52.8 \\
(-5.52)\end{array}$ & $* * *$ & $\begin{array}{l}-35.1^{* * *} \\
(-3.01)\end{array}$ & $\begin{array}{l}-49.0^{* * *} \\
(-5.29)\end{array}$ & $\begin{array}{r}-0.8 \\
(-0.05)\end{array}$ & $\begin{array}{r}20.2 \\
(0.77)\end{array}$ & \\
\hline Year 4 & $\begin{array}{r}-50.8 \\
(-5.08)\end{array}$ & $* * *$ & $\begin{array}{l}-38.8^{* * *} \\
(-3.13)\end{array}$ & $\begin{array}{l}-49.1^{* * *} \\
(-4.92)\end{array}$ & $\begin{array}{r}5.9 \\
(0.38)\end{array}$ & $\begin{array}{r}3.0 \\
(0.11)\end{array}$ & \\
\hline \multicolumn{8}{|c|}{$\begin{array}{l}\text { Additional impact when partner is China, } \\
\text { by year from initiation (in \%) }\end{array}$} \\
\hline China, Year 1 & $\begin{array}{r}4.7 \\
(0.58)\end{array}$ & & $\begin{array}{r}16.9 \\
(1.40)\end{array}$ & $\begin{array}{r}1.4 \\
(0.16)\end{array}$ & & & \\
\hline China, Year 2 & $\begin{array}{r}-5.6 \\
(-0.49)\end{array}$ & & $\begin{array}{r}-3.4 \\
(-0.21)\end{array}$ & $\begin{array}{r}-0.4 \\
(-0.03)\end{array}$ & & & \\
\hline China, Year 3 & $\begin{array}{r}-18.1 \\
(-1.40)\end{array}$ & & $\begin{array}{r}-13.3 \\
(-0.69)\end{array}$ & $\begin{array}{r}-8.6 \\
(-0.42)\end{array}$ & & & \\
\hline China, Year 4 & $\begin{array}{r}-21.6 \\
(-1.59)\end{array}$ & & $\begin{array}{r}-16.0 \\
(-0.76)\end{array}$ & $\begin{array}{r}-20.2 \\
(-0.95)\end{array}$ & & & \\
\hline \multicolumn{8}{|l|}{ Elasticity wrt $\mathrm{AD}$ duties } \\
\hline Year 1 & & & & & $\begin{array}{r}-0.14 \\
(-0.74)\end{array}$ & $\begin{array}{r}-0.20 \\
(-0.75)\end{array}$ & \\
\hline Year 2 & & & & & $\begin{aligned}-0.86 & \text { ** } \\
(-2.33) & \end{aligned}$ & $\begin{array}{r}-1.61 \\
(-3.24)\end{array}$ & \\
\hline Year 3 & & & & & $\begin{array}{l}-1.92 \\
(-3.76)\end{array}$ & $\begin{array}{r}-3.05 \\
(-3.96)\end{array}$ & $* * *$ \\
\hline Year 4 & & & & & $\begin{array}{r}-2.51 \\
(-4.56)\end{array}$ & $\begin{array}{r}-2.99 \\
(-3.32)\end{array}$ & $* * *$ \\
\hline Calendar year fixed effects & Yes & & Yes & No & No & No & \\
\hline R-squared & 0.248 & & 0.290 & 0.181 & 0.159 & 0.242 & \\
\hline Observations & 2350 & & 1337 & 862 & 1583 & 726 & \\
\hline
\end{tabular}

Scope: Manufacturing products. Partners other than China which are not granted MES are excluded from the sample, due to the insufficient number of observations for such cases.

Note: The dependent variable is always expressed in logarithm. For the sake of readability, impacts by year from initiation (either by default or the additional impact for China) are converted in percentage deviations from value at initiation: for instance, the first cell means that, for a partner other than China (i.e. with MES status), one year after investigation of an AD case, import volumes from the target partner are cut by $30.2 \%$ compared to their value during the year of initiation. For each year, the elasticity refers to the coefficients of the independent variable $\ln (1+A D D)$, where $A D D$ is the AVE of the AD duty (or, when applicable, the sum of the $A D$ and the countervailing duty). Standard errors are clustered by individual case. Student's t-statistic in parentheses.

Source: Authors' calculations. For more details on data sources and treatments, see the Appendix.

the EU demand for the product to be neutralized, since it would influence both the numerator and the denominator. Accordingly, year fixed effects are not useful anymore in this case. This specification is consistent with the standard theoretical framework where the elasticity of substitution between imports from different foreign providers is constant.

The results confirm the strong and significant trade-restrictive impact of $A D$ sanctions, consistent with prima facie evidence, with a decline of import volume from the target country assessed to reach $50 \%$ in the first and third specifications, and almost $40 \%$ in the second one (Table 2). These impacts are of the same order of magnitude as those found by Carter and Gunning-Trant (2010) based on US antidumping, but higher than recent results obtained by Lu et al. (2013) using individual data from Chinese exporters. To our knowledge, no other recent study has evaluated them in the EU (studies available are Lasagni, 2000 and Konings et al., 2001).
As is well documented in the literature at least since Prusa (1997), the highest impact found in comparison of other exporters (estimate 3), rather than in absolute (estimate 2), suggests the existence of significant trade diversion effects, meaning that import volumes from partners not targeted by the investigation increase for the products concerned, as a result of substitution across providers. In all cases, this import-cutting impact is not statistically stronger for China.

To better understand the trade impact of $A D$ sanctions, we then take into account the ad valorem equivalent of $A D$ duties in the analysis, based on specifications similar to the ones used so far. Their effect is insignificant in the first year following investigation initiation - not surprisingly, given that this is generally the time it takes to make a final decision, and hence to set the level of final $A D$ duties. In the second to fourth year after investigation, however, the level of $A D$ duties makes a significant difference. The trade-restrictive impact of $A D$ sanctions is then found to be proportional to the level of duties except in the first year.

Following these results, in our preferred specifications (without China additional effects, estimates 4 and 5; see Appendix for additional results), the elasticity with respect to the level of $A D$ duty is estimated to be 2.51 after four years in the simplest specification, and 2.99 when the dependent variable is detrended. This means that a one percent larger duty reduces further import volumes from the targeted partner by approximately $2.51 \%$ and $2.99 \%$, respectively, allowing higher $A D$ duties applied against China to be converted into stronger trade-restrictive impacts.

In each case, estimates point to a larger impact of $A D$ sanctions and of MES status when they are based on detrended variables. This difference is linked to the counterfactual used when assessing $A D$ sanctions. In most cases, $A D$ investigations take place in a context where imports from the target partner(s) are increasing quickly. Such a surge may indicate the beginning of an upward trend, but may also be one-off (in many cases, the trend is actually too large to be held for a long time), and it is not obvious why one hypothesis or the other should be favored. In the latter case, outcomes after investigation should be simply compared to those before investigation. In the former case, in contrast, they should 
be compared to outcomes augmented following pre-investigation trends; detrended variables allow such comparison.

To sum up: the trade-restrictive impact of $A D$ sanctions increases with the level of duties and should therefore be higher against China.

\subsection{AD sanctions increase import prices more for China than for MES partners}

Another important question is the impact of $A D$ cases on import prices, since they are aimed at coping with unfair pricing practices. When exporters targeted by an investigation consider an unfavorable decision to be likely, they have an incentive to increase prices in order to be able to request as soon as possible a review of this decision (and possibly in some cases to influence the odds of an initial sanction). Increased prices are also a way to capture what would otherwise be the revenue of the duty collected by the importing country (Nita \& Zanardi, 2013). We analyze this impact following the same methodology used above for import volumes. The analysis "at face value", without any control, confirms this price-enhancing impact of AD cases (Figure 6). Four years after initiation of the investigation, import unit values are increased by $10 \%$ on average for MES partners, and by $19 \%$ for China. Stronger effects on the unit value of imports from China are not clear unless the most theoretically consistent specification is used (i.e. dividing the partner's import unit values by unit values of untargeted extra-EU importers) and expressing them as a deviation from the pre-investigation trend (see Appendix), denoting the strong decreasing trend in prices preceding a successful $A D$ case against China. Further investigating this impact by controlling for other potential determinants shows that,

Figure 6 - Face value impact of AD cases on import unit values

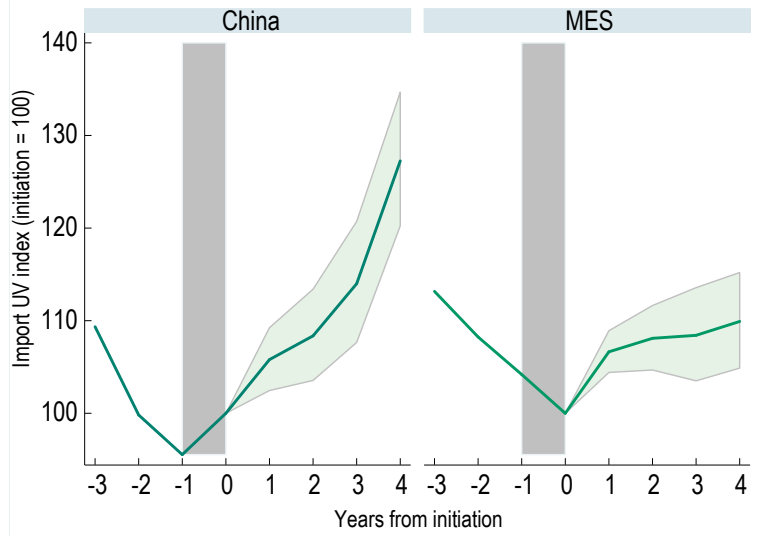

Sample: Same as Figure 5.

Note: The green shaded area represents the [5\%; 95\%] confidence interval, computed from an OLS estimation whereby the change of import unit value (in log) is regressed against time to initiation. The estimating equation is $\ln \left(M U V_{t}^{g} / M U V_{0}^{g}\right)=\mathrm{a}_{\mathrm{t}}+\mathrm{u}_{\mathrm{t}}^{\mathrm{g}}$, where MUV stands for import unit value, $a$ is a parameter and $u$ is an error term. $t$ refers to time (measured as years from initiation) and $g$ to the tariff line targeted. Standard errors are clustered by individual case. While estimated in logarithms, the results are converted to indices for the sake of readability. Using annual data, slopes in the grey shaded areas are irrelevant.

Source: Authors' calculations. For more details on data sources and treatments, see the Appendix. contrary to the effect on quantities, the price-enhancing impact is not linked to the level of the duty.

\section{AD investigations against China have a chilling effect beyond targeted products}

Beyond their direct impact on imports, $A D$ cases can also act as a threat, when the likeliness of facing a case prompts exporters to follow less aggressive commercial strategies, even for products not directly targeted by $A D$ cases. While the notion that $A D$ investigations influence behaviors beyond their direct impact is largely recognized, this specific question of the possible "chilling effect" on untargeted products has received little attention so far: to our knowledge, only two studies explicitly tackle this issue empirically, and they found contrasting results: Egger and Nelson (2010) concluded that spillover effects of $A D$ duties were very limited, while Vandenbusche and Zanardi (2010), focusing on tough new users, found a significant trade-restrictive impact. In any case, none of them addressed the question at issue here, which can be formulated as follows: Can such an effect be identified in the European market, and does it differ as between MES partners and China? Both aspects are relevant, since even a chilling effect common to all $A D$ cases would change the assessment of the decline in the number of $A D$ cases ensuing from MES.

To investigate this question, we take advantage of the fact that, while specifically targeting designated products, $A D$ cases are largely determined by sector-wide variables, such as the capacity of the sector's representatives to coordinate, or their knowledge of $A D$ procedures and experience in the field. $A n A D$ case thus represents a strong signal for untargeted products within the sector that they may well be subject to subsequent investigations. To assess whether this threat really matters, we analyze the impact of an $A D$ case on imports from the targeted partner of other products (not targeted themselves by this or that $A D$ case) within the same HS2 chapter.

If a chilling effect exists, it should materialize in an increase in export prices of untargeted products of the same group. We thus focus our analysis on a Laspeyres index of import unit values for this set of products. To filter out possible interfering factors, such as sector-specific price trends, we apply a difference-in-difference strategy: log unit values are measured as the difference with respect to the log unit value index for the same group of products, for all extra-EU partners not targeted by an AD case; the resulting variable is detrended, using its trend measured between three and one year before initiation of the investigation.

As prima facie evidence, Figure 7 plots, for untargeted products within a chapter targeted by an $A D$ case, the ratio between the average import UV for the targeted partner and the average import UV for untargeted extra-EU partners. As mentioned, the year of investigation initiation is difficult to interpret based on yearly data, meaning that the slope between -1 and 0 is irrelevant here. In the following years, however, import unit values tend to 
Figure 7 - Impact of AD cases on partner's import UV indexes for untargeted products within targeted HS2 chapters (relative level, compared to untargeted extra-EU partners)

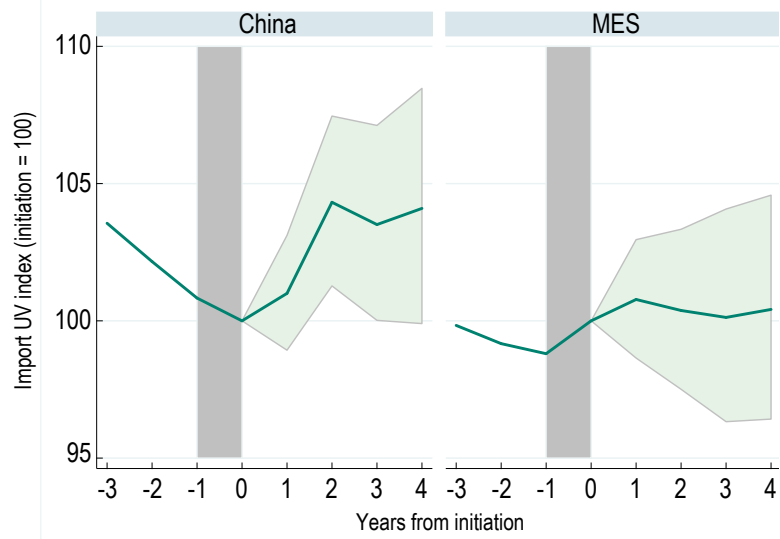

Sample: Same as Figure 5.

Note: The solid line represents the unweighted average across $A D$ cases. The green shaded area represents the [5\%; $95 \%$ ] confidence interval, based on an OLS estimation whereby the change of import unit value (in log) is regressed against time to initiation. The estimating equation is $\ln \left(M U V_{t}^{g} / M U V_{0}^{g}\right)=a_{t}+u_{t}^{g}$, where MUV stands for import unit value, $a$ is a parameter and $u$ is an error term. $t$ refers to time (measured as years from initiation) and $g$ to the tariff line targeted. Standard errors are clustered by individual case. While estimated in logarithms, the results are converted to indices for the sake of readability. Using annual data, slopes in the grey shaded areas are irrelevant.

Source: Authors' calculations. For more details on data sources and treatments, see the Appendix.

move upward for China (by more than $4 \%$ after 4 years), while they stay on par for MES partners. The difference is clearer when pre-investigation trends are accounted for: for China, the upward post-investigation trend takes place after a clearly downward preinvestigation trend, while pre- and post-investigation trends do not display obvious differences for MES partners. Variability across cases is large, though, as illustrated by the wide confidence intervals obtained based on OLS estimates.

Econometric estimates show the statistical significance of this difference, as of the second year following investigation initiation (Table 3). For MES partners, an $A D$ investigation does not influence significantly import UVs on untargeted products within the same HS2 chapter, whatever the specification used. For China, in contrast, import UVs are increased by approximately $4 \%$ on average for untargeted products, relative to other exporters. When the difference is computed based on detrended variables (i.e. assuming implicitly that pre-investigation trends would have been prolonged in the absence of investigation), China's import UVs are found to increase by $7 \%$ after two years, and by more than $14 \%$ after four years, these differences being statistically significant at the $5 \%$ level. While these differences are smaller in magnitude than those on the prices of products directly targeted by $A D$ duties, their economic consequences can be substantial given that they apply to a far wider set of products.

To further investigate the chilling effect, we carry the same analysis at HS4 level (see Appendix for results). The findings are consistent with those at the chapter level: import unit values of other products under the same HS4 heading as a product affected by an $A D$ duty significantly increase when goods are imported from China, even if the identification of this effect is less clear because of smaller samples. This increase is larger than at the HS2 level, as expected, since HS4 headings gather products more similar to those affected by $A D$ and therefore more likely to be targeted by complaining industries. These results confirm the robustness of the chilling effect at the HS2 chapter level.

Summing up: For China, $A D$ investigations have a chilling effect on untargeted products belonging to the same sector as those directly targeted. This effect, which materializes through $4 \%$ to $14 \%$ price increases on average, is not retrieved for MES partners.

\section{Taking stock and simulating the global impact of granting China MES}

The empirical results above make it possible to address the main question at stake here: What difference would it make if China were treated the same way as MES partners are in EU AD? To do that, we take into account each of the different ways in which MES may influence $A D$ outcomes, as identified above, and carry out
Table 3 - Estimated impact of AD cases on import unit values for MES partners and additional impact for China - HS2 Chapter level

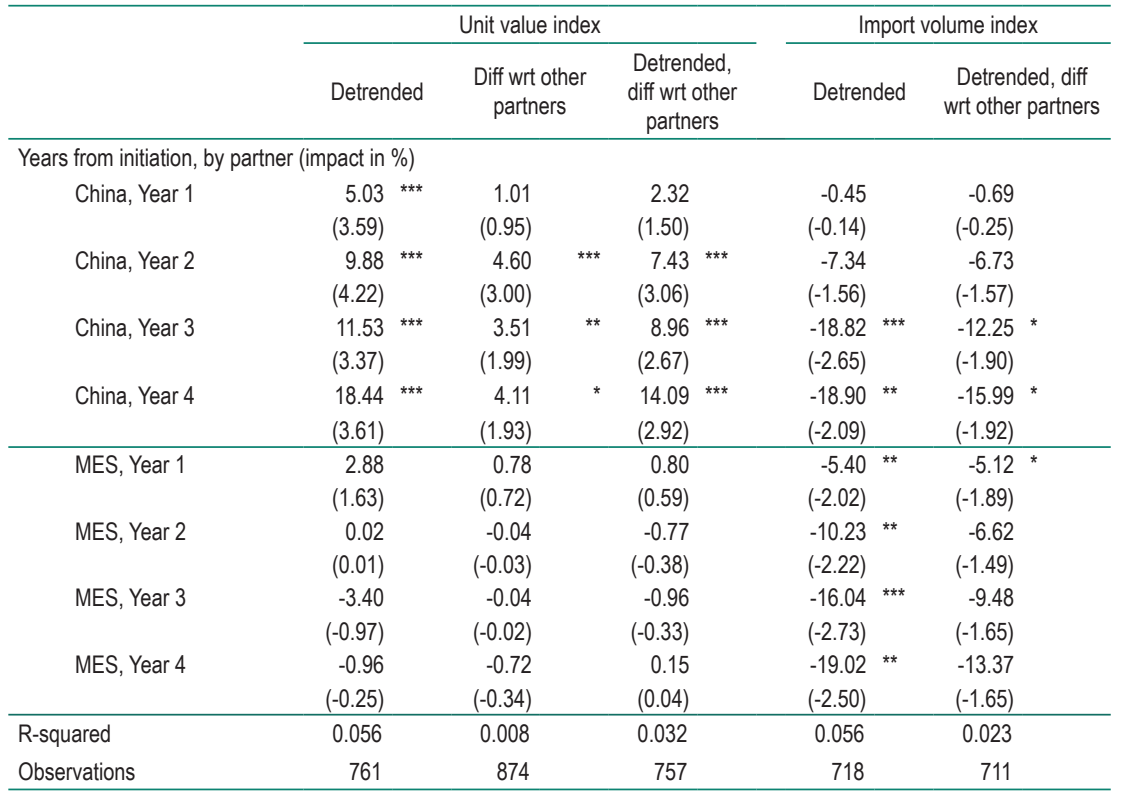

Scope: Same as Figure 5.

Source: Authors' calculations. For more details on data sources and treatments, see the Appendix. 
counterfactual simulations of trade and output, assuming away China's estimated specificities. The latest year available, 2014, is thus compared to a counterfactual situation where China would have been treated as a market economy since the initiation of all active cases.

Before presenting in more detail the simulation approach and results, three important remarks are in order. First, as mentioned in the introduction, part of China's specificities might be due not only to its status, but also to its different practices, meaning that assuming them away might actually overestimate the consequences of MES.

Secondly, the simulations are carried out in a partial equilibrium setup, assuming unchanged producer prices, factor prices, total income (excluding tax receipts) and nominal exchange rates. As such, the ceteris paribus assessment proposed in what follows disregards possible adjustments ensuing from this policy change over and above the direct impacts identified. This is a shortcoming, especially in the long term, and the impacts identified here are best understood as direct, short-term ones.

Thirdly, assessing consistently the employment consequences would require evaluating the complex indirect effects involved through input-output relationships as well as general equilibrium effects. This is beyond the scope of this work, which focuses on detailed trade analysis in a partial equilibrium setup, but the orders of magnitude are clearly significant, most of all taking into account the fact that indirect effects, included in non-manufacturing sectors, can be several times larger than direct ones, and that local labor-market adjustment may be slow and painful. ${ }^{12}$ Accordingly, no welfare analysis is carried out either, even though consumer gains ensuing from lower prices are identified.

In practice, to characterize the counterfactual situation where China benefits from MES, we assume that only Chinese products facing an AD duty in 2014 would be likely to face one under MES. Three questions then arise: (i) What is the probability that an antidumping duty active in 2014 is removed under MES?; (ii) Under MES, if the case is not removed, how are imports from China affected by the removal of or decrease in duties?; (iii) What are the impacts on domestic production of the resulting increase in imports from China?

Each of these questions is treated based on the empirical results above. A rather standard theoretical framework (detailed in the Appendix) is then used to simulate consistently the resulting impacts. It encompasses substitutability with constant elasticity between imports from different source countries, and between imports and domestic production (additional estimations are carried out in this respect). Substitution is also possible between goods and between goods and services, with a constant elasticity equal to -0.2 .

(12) Analyzing the consequences of Chinese competition in the US, Acemoglu et al. (2014) evaluate direct employment effects in the manufacturing sector as translating into three to four times larger total employment effects, almost half of them outside manufacturing. Autor et al. (2016) show in addition that local labormarkets impacts may remain significant for a full decade at least.
As already mentioned, estimates point to a larger impact of $A D$ sanctions and of MES status when they are based on detrended variables; it remains arguable whether detrending should be carried out or not. We thus retain each of these two sets of results as a possible parameterization of our simulations, considering estimates based on variables in levels as conservative, and those based on detrended estimates as upper ones. In each case, we use as a benchmark value the mean of parameter estimates for three and four years after initiation, i.e. at a time when a final decision is reached in almost all cases.

We first simulate the impact of China's MES, focusing on direct impacts only (scenario "MES" below). We then take into account the chilling effect on untargeted products within targeted HS2 chapters: since our estimates suggest that such an effect only holds for China, we assume that the lower threat associated with MES would result in the disappearance of this effect (scenario "MES \& chilling effect"). This is modeled as an exogenous decline in Chinese import prices within the relevant HS2 chapters, amounting to $3.8 \%$ (conservative estimate, mean over three and four years after investigation) or $11.5 \%$ (upper estimate). An additional scenario is considered where, in addition to granting MES to China, the EU drops the lesser duty rule in its $A D$ procedures (scenario "MES \& chilling effect \& LDR dropped").

\subsection{Granting China MES leads to a sizeable increase in Chinese imports but a limited impact on domestic production}

In this partial equilibrium setup, where any potential balancing effect is assumed away, granting China MES decreases the number of $A D$ sanctions against Chinese exports and reduces $A D$ duties and their trade impact on each remaining sanction. ${ }^{13}$ Unequivocally, the result is an increase in EU imports from China. Even disregarding the chilling effect, this increase is not trivial, amounting to $3.9 \%$ in volume terms (i.e., at initial prices, tax exclusive) under our conservative estimates, and 5.3\% under the upper one (Table 4, columns 1 and 2). In both cases, around $90 \%$ of these effects come from the reduction in the number of sanctions, the rest reflecting the decrease in the remaining $A D$ duties. The chilling effect changes the order of magnitude of the impact, though, suggesting that EU imports from China might increase by up to $21 \%$ based on our upper estimates, a huge impact for such an important trade relationship. Since EU manufacturing imports from China amounted to $€ 342$ bn in 2015 according to Eurostat, this would correspond to an increase of $€ 72$ bn at initial prices. Noteworthily, changes in EU imports from China are lesser when measured in tax inclusive value at current prices, because of reduced AD duties as well as lower export prices resulting from dropping the chilling effect, when applicable.

(13) Note that we do not consider changes in duties made by AD reviews. In particular, anti-circumvention reviews can lead to application of the highest $A D$ duty (ADD) applied against China to a third country found to be used by China to circumvent AD measures. Granting China MES might then probably result in the reduction or removal of these anti-circumvention duties. 
Table 4 - Simulated impacts of granting China MES

\begin{tabular}{|c|c|c|c|c|c|c|}
\hline \multirow{5}{*}{$\begin{array}{l}\text { Chilling effect impact } \\
\text { Estimate } \\
\text { Lesser duty rule droped }\end{array}$} & \multicolumn{2}{|c|}{ MES } & \multicolumn{2}{|c|}{$\begin{array}{c}\text { MES } \\
\text { \& Chilling effect }\end{array}$} & \multicolumn{2}{|c|}{$\begin{array}{l}\text { MES \& Chilling effect } \\
\text { \& LDR dropped }\end{array}$} \\
\hline & No & No & Yes & Yes & Yes & Yes \\
\hline & Conserv. & Upper & Conserv. & Upper & Conserv. & Upper \\
\hline & No & No & No & No & Yes & Yes \\
\hline & $(1)$ & $(2)$ & (3) & (4) & (5) & (6) \\
\hline \multicolumn{7}{|l|}{ Changes in \% } \\
\hline \multicolumn{7}{|l|}{ Manuf. imports from China } \\
\hline Value at initial prices, tax exclusive & 3.9 & 5.3 & 7.4 & 21 & 7.3 & 21 \\
\hline Value at current prices, tax inclusive & 0.8 & 1.7 & 2.2 & 9.5 & 2.1 & 9.4 \\
\hline Manuf. imports from other partners & -0.3 & -0.5 & -0.8 & -2.9 & -0.8 & -2.9 \\
\hline Domestic manufacturing output & -0.04 & -0.06 & -0.11 & -0.32 & -0.11 & -0.32 \\
\hline Goods targeted by ADD in 2014 & -1.9 & -2.5 & -1.9 & -2.4 & -1.8 & -2.3 \\
\hline Goods not targeted by ADD in 2014 & 0.00 & 0.00 & -0.07 & -0.28 & -0.07 & -0.28 \\
\hline Demand-side gains (\% of manuf. demand) & 0.00 & 0.01 & 0.02 & 0.33 & 0.02 & 0.3 \\
\hline \multicolumn{7}{|l|}{ Changes in $\mathrm{Bn} €(2015)$} \\
\hline \multicolumn{7}{|l|}{ Manuf. imports from China } \\
\hline Value at initial prices, tax exclusive & 13 & 18 & 25 & 72 & 25 & 72 \\
\hline Value at current prices, tax inclusive & 2.9 & 5.9 & 7.4 & 32 & 7.2 & 32 \\
\hline Manuf. imports from other partners & -2.8 & -4.2 & -7.0 & -24 & -6.9 & -24 \\
\hline Domestic manufacturing output & -3.1 & -3.9 & -7.9 & -23 & -7.8 & -23 \\
\hline Goods targeted by ADD in 2014 & -2.7 & -3.6 & -2.7 & -3.5 & -2.6 & -3.4 \\
\hline Goods not targeted by ADD in 2014 & -0.3 & -0.3 & -5.2 & -19 & -5.2 & -19 \\
\hline Demand-side gains & 0.05 & 0.7 & 1.4 & 22 & 1.3 & 22 \\
\hline
\end{tabular}

Note: See Appendix for methodological details. Simulations are based on year 2014. Proportional impacts are converted in euros based on 2015 values of trade and output. For items other than imports from China, changes in volume or in value at initial prices are the same as changes in value (either tax inclusive or not), since prices and taxes are assumed unchanged. Demand-side gains are computed as an equivalent variation of income (see Appendix for details).

Source: Authors' calculations. For more details on data sources and treatments, see the Appendix.

For consumers, either final or intermediate, changing China's status results in lower $A D$ duties and therefore lower import prices. This import price decrease is by definition even stronger when the removal of the chilling effect is taken into account. The corresponding purchasing power gains are in all cases larger than tariff receipt losses. Resulting "demandside gains" (encompassing the sum of these two components), measured here as equivalent variations of income, are significant but limited as a result of direct impacts, amounting at most to $0.01 \%$ of demand of manufacturing products, or $€ 0.7 \mathrm{bn}$. However, they may be large (up to $0.33 \%$ of demand) as a result of the removal of the chilling effect, since this would trigger a significant decline in import prices. Noteworthily, these

These additional imports would displace sales by Chinese competitors. The most directly affected are other extraEU providers, since substitutability is higher among foreign providers than between imports and domestic products, as amply documented in the literature (Feenstra et al., 2014, is a recent illustration) and confirmed by our estimates (see Appendix). With China accounting for close to $30 \%$ of extra-EU manufacturing imports in 2015, these effects are significant, resulting in a decrease of EU imports from other partners by $0.3 \%$ to $0.5 \%$ disregarding the chilling effect, and by up to $2.9 \%$ taking it into account. Based on 2015 trade flows, the upper-bound impact would correspond to a decrease in imports from extra-EU partners other than China by $€ 24 \mathrm{bn}$.

Being less substitutable to Chinese imports and larger in value, domestic products are less affected proportionately: domestic output is reduced by $0.04 \%$ to $0.06 \%$ in the base case, and by up to $0.32 \%$ when the chilling effect is accounted for. While small, these figures are far from negligible, insofar as they concern total manufacturing output: the corresponding values of output decline based on 2015 figures would be $€ 1$.8bn and $€ 2$. $6 \mathrm{bn}$ in the first two cases, and $€ 23 \mathrm{bn}$ in the latter case. Output losses are always far stronger on products directly targeted by $A D$ sanctions against China. In relative terms, output losses linked to direct effects would be highest in HS Chapters 69 (ceramic products), 76 (aluminum and articles thereof), 81 (other base metals), 70 (glass and glassware) and 85 (electrical machinery and equipment). numbers cannot be meaningfully compared to output losses. As already mentioned, no aggregate welfare analysis is attempted here.

\subsection{Removing the lesser duty rule would have very small impact}

The discussion around China's status has renewed questions about a possible reform of the EU's trade defense instruments. One aspect of specific interest can be evaluated in the present framework, namely the so-called "lesser duty rule" (LDR). As already mentioned, when an $A D$ investigation concludes that sanctions are in order, the EU does not always apply duties equal to the dumping margin, as is possible according to WTO agreements and as is practiced by other countries. In contrast, it applies duties equal to the lesser of two levels: the dumping margin and the injury margin, defined as the duty required to remove the injury to the European industries.

In 2015, the LDR applied to 32 out of 51 ongoing AD duties against China, reducing applied duties by 27.9 percentage points for these cases (Table 5). For other partners, the LDR is applied less often, in 16 out of 36 cases, and it reduces duties by a lesser extent, by 15.1 p.p. on average. On average across all cases, the difference is thus far larger for China (19 p.p.) than for MES partners (7.4 p.p.).

To assess to what extent it matters practically, two additional simulations were carried out assuming the LDR to be dropped in cases against China, in addition to the change in China's MES. In 
Table 5 - Statistics on the use and tariff impacts of the lesser duty rule

\begin{tabular}{lcccc}
\hline & \multicolumn{4}{c}{ Lesser Duty Rule Application } \\
\cline { 2 - 5 } & No & Yes & Not Applicable & Total \\
\hline MES Partners & 24.1 & 18.0 & & 21.1 \\
ADD applied (\%) & 24.1 & 33.1 & & 28.5 \\
ADD w/o LDR (\%) & 17 & 16 & 3 & 36 \\
Nb cases & & & & \\
\hline China & 49.3 & 44.1 & & 45.8 \\
ADD applied (\%) & 49.3 & 72.0 & & 64.8 \\
ADD w/o LDR (\%) & 15 & 32 & 4 & 51 \\
Nb cases & & & & \\
\hline
\end{tabular}

Sample: Cases active in 2015, against China and MES, in which an ad valorem equivalent of the measure in force can be calculated.

Source: Authors' calculations. For more details on data sources and treatments, see the Appendix.

practice, $A D$ duties in existing cases are assumed to be replaced by the dumping margins assessed in published investigation documents. According to our results, removing the LDR would hardly change the impact of changing China's status (Table 4, columns 5 and 6). This result may seem surprising given the importance devoted to this issue in recent discussion. It is explained by two factors: first and chiefly, $90 \%$ of the impacts of changing China's status are caused by cancelled $A D$ duties (as opposed to reduced $A D$ duties when cases are maintained), on which the removal of the LDR has no impact; second, if cases against MES partners are any guide, removing the LDR would only slightly alter the level of duties applied against China once it benefits from MES.

\section{Implications for EU's AD policy: MES, not MES or a broader reform?}

Assessing the potential economic implications of changing China's status in EU's policy requires many simplifying assumptions; the results should be interpreted bearing in mind the limitations and specific focus of such an exercise. In particular, the partialequilibrium assessment of direct impacts on trade and output proposed here overlooks ensuing endogenous adjustments. Accordingly, it does not try to evaluate the consequences on employment or welfare. It should also be emphasized again that it did not prove possible to disentangle to what extent China's specificities are linked to its status or to its practices, meaning that our assessment, based on the assumption that China's specificities are suppressed in the EU's AD, may overestimate the impact. Allowing for these caveats, our results suggest that granting MES to China may have sizeable economic impacts, with multibillion stakes in terms of potential increase in EU imports from China, but also of potential decline of EU imports from other partners, and of domestic manufacturing output. The chilling effect originated by $A D$ cases upon untargeted, similar products under the current status explains the bulk of these impacts, but they remain significant even when disregarding such effects.

Nevertheless, even though status quo is the benchmark of our simulations since it is a well-known, easy-to-characterize situation, it is not necessarily a realistic option. Indeed, the Chinese government interprets the expiration of the provisions of subparagraph (a)(ii) of its accession protocol as meaning that MES should be granted to China. It is thus likely to interpret a refusal to grant this status as impairing the benefits China can expect from its partners' commitments under the WTO, and to bring the case to the organization's Dispute Settlement Body. Without prejudice of the outcome, two important consequences have to be considered. First, the stakes of a possible WTO dispute could reach a magnitude unparalleled so far, according to our simulations. China might be authorized to suspend benefits for a huge amount of trade coming from Europe, with potentially serious consequences in some European sectors or areas. Second, even if the outcome of a WTO dispute can take several years, other kinds of retaliations, such as restrictions not formally linked to the issue and political pressures, cannot be ruled out in addition. Previous episodes, like the solar-panel dispute, exemplify what form they might take, even if they concerned smaller trade flows. ${ }^{14}$ More generally, the response given by the EU may have farreaching implications for the multilateral system. The EU not only ranks first in foreign trade of goods and services, it also played a key role in building the relevant institutions, and has been one of the multilateral system's main supporters up to now. Inconsistent application of multilateral commitments by the EU in such an important situation could be expected to damage seriously the credibility of the rule-based system built under the WTO. Not granting China MES can be seen as inconsistent with EU commitments, especially as NME status has never been a central part of multilateral agreements; it was introduced as a detail to cope with the Cold War context (in the second addendum to GATT Article VI) and was never elaborated upon in subsequent $A D$ agreements. Specific methodologies have never been defined by the WTO, and member states have used this concept in a heterogeneous and often patchy manner. The EU, for instance, has been maintaining a list of NMEs since 1968, but never defined legally the criteria used to build it (see Box 1). NME status has thus never been thought of as an important component of WTO agreements, meaning that its legitimacy when dealing with issues of importance is limited in this context.

This being said, we are now in a new and peculiar situation, where the world's leading exporter of merchandise is a communist country where, despite the remarkable ongoing transition process, the state still plays a central role. Its influence materializes in multiple ways, from the importance of state-owned enterprises to the targeted use of taxation and the massive distortion of input prices, especially obvious as far as financing conditions are concerned. Dealing with this situation is a serious challenge for a multilateral trading system that relies on the principle of fair and equitable competition between market economies. In this context, it is legitimate for the EU to question the fairness of China's

(14) In 2012, trade in HS lines involved in the AD case against Chinese exporters of solar panels amounted to $8.3 \mathrm{bn}$. Price undertakings were negotiated after China threatened and effectively opened $A D$ investigations into wine imports from the EU. 
practices in terms of international competition, and to make sure it is in a position to redress unfair practices in an efficient and timely manner. Realism also commands retaining bargaining power against a still largely centralized trade superpower whose policy priorities may prove disruptive for its foreign partners. A reform of the EU's trade defense instruments is necessary to do this, as is already being discussed. Its objectives should be to enhance the efficiency of these instruments, while abiding by the rules of multilateral agreements. In the present situation, where some of the sectors most protected by $A D$ are hard hit by a crisis caused by overcapacities, it is important to bear in mind that $A D$ procedures are supposed to deal with specific unfair practices and are not restructuring policies. They do not qualify as good instruments in this respect. Eligibility is not designed consistently with such kinds of objectives; no condition is imposed on firms benefiting from the protection, and the costs imposed on third parties through higher prices can be excessive. Still, when unfair trade practices are at stake, using $A D$ sanctions is legitimate provided their use follows internationally agreed principles, and maximizing their efficiency and timeliness are legitimate objectives.

Comparing EU practices to US ones might be useful in this respect, but it is important to bear in mind the shortcomings and limitations of US practices (see Box 2). While the US is a tough user of antidumping, it has frequently taken liberties with its international commitments, and has been repeatedly condemned in dispute settlement at the WTO. The fact that its AD system generates very high duties is not a proof of efficiency, and our estimates suggest that lower duties such as those applied in the EU are sufficient to sanction unfair practices and to limit drastically their consequences

More generally, the impact assessment presented here gives insights into the possible EU reforms. Our simulations suggest that dropping the LDR is unlikely to make a significant difference. It would increase somewhat the AD duties applied, but would not alter significantly the nature and magnitude of the consequences. As a matter of fact, the key lies more in the possibility of quickly and successfully raising a case when it is justified, than in the level of sanctions applied subsequently. Allowing ex officio investigations and protecting potential plaintiffs against retaliation seem more promising routes of reform in this respect.

If any doubt remained, our assessment confirms the utter importance of China's status in EU antidumping policy. Beyond the bilateral relationship, the response found will be a test for the capacity of the EU to abide by its commitment to a principled, rule-based multilateral system, while facing the paradoxes of the present situation, where the leading world trader is a communist country.

\section{References}

Acemoglu, D., Autor, D. H. , Dorn, D., Hanson, G. H. \& Price, B. Import Competition and the Great U.S. Employment Sag of the 2000s National Bureau of Economic Research, 2014

Autor, D. H., Dorn, D., \& Hanson, G. H. (2016). The China shock: Learning from labor market adjustment to large changes in trade. Annual Review of Economics, 8(1).

Blonigen, B. A. \& Park, J.-H. (2004). Dynamic pricing in the presence of antidumping policy: Theory and evidence. American Economic Review, 94(1), 134-154.

Blonigen, B. A. \& Prusa, T. J. (2015). Dumping and anti-dumping duties. Working paper 21573, NBER.

Bown, C. P. (2011). Taking stock of antidumping, safeguards and countervailing duties, 1990-2009. The World Economy, 34(12), 1955-1998.

Bown, C. P. (2015) "Global Antidumping Database," The World Bank, June, available at http://econ.worldbank.org/ttbd/gad/

Bown, C. P. \& Crowley, M. A. (2013) Import protection, business cycles, and exchange rates: Evidence from the Great Recession Journal of International Economics, Elsevier BV, 2013, 90, 50-64.

Bown, C. P. \& Crowley, M. A. (2016). The empirical landscape of trade policy. Policy Research Working Paper 7620, World Bank.

Carter, C. A. \& Gunning-Trant, C. (2010). U.S. trade remedy law and agriculture: trade diversion and investigation effects. Canadian Journal of Economics/Revue canadienne d'économie, 43(1), 97-126.

Durling, J. P. \& Prusa, T. J. (2006). The trade effects associated with an antidumping epidemic: The hot-rolled steel market, 1996- 2001. European Journal of Political Economy, 22(3), 675-695.

EC (2015a). Commission Staff Working Document accompanying the document "33rd Annual Report from the Commission to the Council and the European Parliament on the EU's Anti-Dumping, Anti-Subsidy and Safeguard activities (2014)". COM(2015) 385 final, European Commission. EC (2015b). Notice of initiation of an expiry review of the anti-dumping measures applicable to imports of crystalline silicon photovoltaic modules and key components (i.e. cells) originating in or consigned from the People's Republic of China. European Commission.

Egger, P. \& Nelson, D. (2011). How bad is antidumping? Evidence from panel data. Review of Economics and Statistics, 93(4), 1374-1390.

Feenstra, R., Luck, P., Obstfeld, M., \& Russ, K. (2014). In Search of the Armington Elasticity. Working Paper 20063, NBER.

GAO (2006). U.S. - China trade - Eliminating nonmarket economy methodology would lower antidumping duties for some Chinese companies. United States Government Accountability Office.

Konings, J., Vandenbussche, H., \& Springael, L. (2001). Import diversion under European antidumping policy. Journal of Industry, Competition and Trade, 1(3), 283-299

Lasagni, A. (2000). Does country-targeted anti-dumping policy by the EU create trade diversion? Journal of World Trade, 34(4), 137-160.

Lu, Y., Tao, Z., \& Zhang, Y. (2013). How do exporters respond to antidumping investigations? Journal of International Economics, 91(2), 290-300.

Nita, A. C. \& Zanardi, M. (2013). The first review of European Union antidumping reviews. The World Economy, 36(12), 1455-1477.

Prusa, T. J. (1992). Why are so many antidumping petitions withdrawn? Journal of International Economics, 33(1-2), 1-20.

Prusa, T. J. (1997). The Trade Effects of U.S. Antidumping Actions, (pp. 191-214). University of Chicago Press.

Puccio, L. (2015). Granting Market Economy Status to China. Indepth analysis, European Parliamentary Research Service - European Parliament.

Van Bael, I. \& Bellis, J. (2011). EU Anti-Dumping and Other Trade Defence Instruments. Wolters Kluwer Law \& Business.

Vandenbussche, H. \& Zanardi, M. (2010). The chilling trade effects of antidumping proliferation. European Economic Review, 54(6), 760-777.

Veugelers, R. \& Vandenbussche, H. (1999). European anti-dumping policy and the profitability of national and international collusion. European Economic Review, 43.

Zanardi, M. (2004). Antidumping law as a collusive device. The Canadian Journal of Economics / Revue canadienne d'Economie, 37(1), 95-122. 


\section{About the authors}

Cecilia Bellora is Economist in the Trade Policy team of CEPII.

Sébastien Jean is Director of CEPII.

The authors are grateful to Kevin Lefebvre for providing outstanding research assistance.

Contact: beatrice.postec@cepii.fr

\section{Previous Issues}

Transatlantic Trade: Whither Partnership, Which Economic Consequences? by Lionel Fontagné, Julien Gourdon \& Sébastien Jean, No 1, September 2013. Can the Euro Area Avoid a "Lost Decade"? by Benjamin Carton, Jérôme Héricourt \& Fabien Tripier, No 2, April 2014.

China's Roadmap to Harmonious Society - Third Plenum Decisions on "major issues concerning comprehensively deepening reforms" by Michel Aglietta \& Guo Bai, No 3, May 2014.

A New Architecture for Public Investment in Europe: The Eurosystem of Investment Banks and the Fede Fund by Natacha Valla, Thomas Brand \& Sébastien Doisy, No 4, July 2014.

Central Bank Currency Swaps and the International Monetary System? by Christophe Destais, No 5, September 2014.

Financing energy and low-carbon investment: public guarantees and the ECB by Michel Aglietta \& Étienne Espagne, № 6, March 2015.

A Holistic Approach to ECB Ass et Purchases, the Investment Planand CMU by Natacha Valla, Jesper Berg, Laurent Clerc, Olivier Garnier \& Erik Nielsen, No 7, April 2015.

Currency Turmoil in an Unbalanced World Economy by Michel Aglietta \& Virginie Coudert, No 8, July 2015.

Climate Finance at COP21 and After: Lessons Learnt, Étienne Espagne, No 9, February 2016.

International Financial Flows in the New Normal: Key Patterns (and Why We Should Care) by Matthieu Bussière, Julia Schmidt \& Natacha Valla, No 10, March 2016.

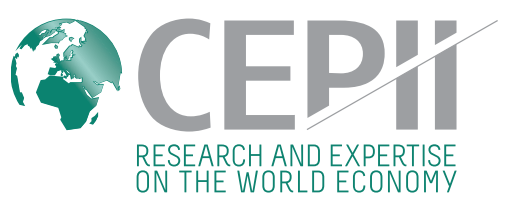

CEPII (Centre d'Etudes Prospectives et d'Informations Internationales) is a French institute dedicated to producing independent, policy-oriented economic research helpful to understand the international economic environment and challenges in the areas of trade policy, competitiveness, macroeconomics, international finance and growth.
CEPII Policy Brief

CEPII's insights on international economic policy

CEPII - Paris - 2016 No ISSN: 2270-258X

All rights reserved. Opinions expressed in this publication are those of the author(s) alone.

Editorial Director: Sébastien Jean

Managing Editor: Christophe Destais

Production: Laure Boivin
CEPII

113 , rue de Grenelle

75007 Paris

+33153685500

www.cepii.fr

Press contact: presse@cepii.fr 